УдК 616.31-084:577.3:616.72-002.77-053

DOI 10.11603/2311-9624.2016.3.6840

СВ. М. Кулигіна, О. Ю. Пилипюк

Вінницький національний медичний університет імені М. І. Пирогова

\title{
Динаміка стану гігієни порожнини рота, фізико-хімічних та мінералізуючих властивостей ротової рідини після лікування дітей $з$ ювенільним ревматоїдним артритом
}

Резюме. Проведено вивчення ефективності комплексу лікування і профілактики карієсу зубів у 29 дітей другого дитинства (15 основної і 14 порівняльної груп) і 26 підліткового віку (по 13 осіб у кожній групі) - за показниками стану гігієни порожнини рота, фізико-хімічних та ремінералізуючих властивостей ротової рідини. Висока ефективність розпрацьованого методу підтверджувалась достовірним підвищенням кислотно-лужного стану порожнини рота, поліпшенням рівня її індивідуальної гігієни і структурних властивостей ротової рідини та суттєвим впливом на інтенсивність слиновиділення, що забезпечувало реалізацію важливих ремінералізуючих функцій змішаної слини.

Ключові слова: карієс зубів, діти, ЮРА, лікування, профілактика.

\section{В. Н. Кулыгина, О. Ю. Пилипюк}

Винницкий национальный медицинский университет имени Н. И. Пирогова

\section{Динамика состояния гигиены полости рта, физико-химических и минерализующих свойств ротовой жидкости после лечение детей с ювенильным ревматоидным артритом}

Резюме. Проведено изучение эффективности комплекса лечения и профилактики кариеса зубов у 29 детей второго детства (15 основной и 14 сравнительной групп) и 26 подросткового возраста (по 13 человек в каждой группе) - по показателям состояния гигиены полости рта, физико-химических и реминерализирующих свойств ротовой жидкости. Высокая эффективность предложеного метода подтверждалась достоверным повышением кислотно-щелочного состояния полости рта, улучшением уровня ее индивидуальной гигиены и структурных свойств ротовой жидкости и существенным влиянием на интенсивность слюноотделения, что обеспечивало реализацию важных реминерализирующих функций смешанной слюны.

Ключевые слова: кариес зубов, дети, ЮРА, лечение, профилактика.

\author{
V. M. Kulyhina, O. Yu. Pylypiuk
}

M. Pyrohov Vinnytsia National Medical University

\section{Dynamics of oral hygiene, physical, chemical and mineralizing properties of oral liquid after treatment of children with juvenile rheumatoid arthritis}

Summary. The study of the efficiency of complex treatment and prevention of dental caries of 29 children of the second childhood (15 primary and 14 comparative group) and 26 children of juvenile age (13 persons in each group) - in terms of the state of oral health, physical, chemical and reminerilizing properties of oral fluid. The high efficiency of the proposed method was confirmed by a significant increase in the acid-base status mouth, improving the level of personal hygiene and structural properties of oral fluid and significant influence on the intensity of salivation, thus ensuring implementation of important functions of reminerilizing mixed saliva.

Key words: dental caries, children, juvenile rheumatoid arthritis, treatment, prevention. 
Вступ. Результати досліджень, що подані науковцями [1, 8], свідчать про розвиток захворювань зубів, тканин пародонта та СОПР при ревматоїдному артриті. Окремі роботи присвячені ураженню твердих тканин зубів у дітей з ювенільним ревматоїдним артритом (ЮРА) [3, 4].

У житті сучасної людини гігієна порожнини рота займає суттєве місце, забезпечуючи не тільки комфортний стан у роті, а й здійснюючи визначену лікувально-профілактичну функцію. Проте позитивний вплив на стан порожнини рота, що має значення у загальному оздоровленні організму дитини, впливають властивості середовища: $\mathrm{pH}$ ротової рідини та швидкість слиновиділення. Крім того, при ЮРА велике значення мають ремінералізуючі властивості ротової рідини, які визначають ступінь ураження твердих тканин зубів каріозним процесом. Попередньо в наших дослідженнях встановлено погіршення показників гігієни ротової порожнини, швидкості слиновиділення змішаної слини та їі ремінералізуючих властивостей у зазначеної категорії дітей [7]. Тому актуальність проблеми диктує необхідність розробки ефективного методу лікування і профілактики розвитку каріозного ураження зубів у дітей з ЮРА та визначення його ефективності, що недостатньо представлено в літературі.

Метою роботи було вивчити зміни стану гігієни ротової порожнини, фізико-хімічних та мінералізуючих властивостей ротової рідини в процесі лікування дітей з ЮРА.

Матеріали і методи. Для досягнення поставленої мети проведено обстеження 55-ти дітей з ЮРА, які за класифікацією В. І. Берзіня поділено на дві групи: 29 - другого дитинства (8-12 років) і 26 - підліткового віку (13-16 років). За методом лікування поділ обстежених пацієнтів був таким: основну групу склали 15 дітей з ювенільним ревматоїдним артритом віком 8-12 років; 13 - віком 13-16 років, порівняльну відповідно 14 і 13 осіб.

Ротову рідину для дослідження збирали протягом 15 хв після полоскання порожнини рота дистильованою водою без стимуляції слиновиділення. Швидкість слиновиділення за певний проміжок часу визначали за формулою: Шс=V/T, де Шс - швидкість слиновиділення (у мЛ/хв), V - об'єм виділеної слини (в мл), Т - час забору слини (у хв). Визначення $\mathrm{pH}$ ротової рідини проводили за допомогою тесту Saliva Check. Оцінку стійкості зубів до карієсу та ре- мінералізуючих властивостей ротової рідини виконували за методикою Т. Л. Рединовой (В. Ф. Михальченко, 2006), мікрокристалізуючого потенціалу слини - за методом Т. Л. Рединовой і А. Р. Поздеева [10]. Гігієну порожнини рота визначали за індексом Гріна-Вермільйона [12].

Лікування основної та порівняльної груп дітей $з$ ЮРА залежало від форми процесу, активності та його тривалості, і включало базисну медикаментозну терапію: «Метотрексат» внутрішньом'язово - по 10-20 мг/ $\mathrm{M}^{2} 1$ раз на тиждень, розділяючи розраховану дозу на 2 ін'єкції з 12-годинним інтервалом (до досягнення стійкої ремісії тривалістю не менш як в двароки); «Метипред»(внутрішньосуглобове)(0,2-0,7-1 мл залежно від величини суглобів) один раз у 3-6 місяців для зняття запального процесу та набряку в суглобах, або перорально - по 0,8-1,5 мг/кг до настання ремісії, після чого дозу поступово знижують за схемою до мінімальної, з подальшою відміною препарату, або за показаннями - одночасне застосування; «Фолієва кислота» - по 5 мг перорально 1 раз на тиждень у дні вільні від введення препарату «Метотрексат»; «Терафлекс» - по 1 капсулі 2-3 рази на добу протягом місяця; «Вольтарен» - у вигляді таблеток по 3-5 мг/кг 2-3 рази на день у періоді загострення; мінерально-вітамінний комплекс «Кальцемін» дітям старше 12 років - по 1 таблетці 2 р./д., дітям з 5 до 12 років - по 1 таблетці 1 р./д. протягом місяця. За відсутності позитивних клінічних результатів при лікуванні ЮРА за базовою методикою, дітям призначали препарат біологічної дії «Хуміра» (п/к 40 мг 1 раз на два тижні) в якості монотерапії або у поєднанні 3 метотрексатом. Немедикаментозне лікування ЮРА включало: ЛФК (проводили відповідно до індивідуальних можливостей хворої дитини); дієту (іжа з підвищеним вмістом кальцію та вітаміном D для профілактики остеопорозу); режим (обмеження рухової активності дитини; біг, стрибки, активні вправи - небажані; обмеження психоемоційного навантаження, перебування на сонці; рекомендовано спати на жорсткому матраці та тонкій подушці, зберігати пряму поставу при ходьбі та сидінні); фізіотерапію (за показаннями - масаж суглобів, лазеромагнітна терапія, парафінотерапія).

Лікувально-профілактичний комплекс щодо ураження зубів каріозним процесом у дітей основної та порівняльної груп з ЮРА проводили з урахуванням ряду заходів загального і 
місцевого характеру, а також стадії розвитку патологічного процесу в твердих тканинах зубів. Здійснювали професійне чищення зубів із застосуванням торцевої обертової щіточки зі штучною нейлоновою щетиною та полірувальної пасти без фтору з низьким ступенем абразивності («Superpolish», $\phi$. «Kerr», Швейцарія) зі швидкістю 3000-5000 об./хв протягом 2 хв. Зважаючи на переважання гострих форм каріозного процесу в дітей з ЮРА, в основній групі надавали перевагу сучасним ефективним методам лікування. Для лікування гострого початкового карієсу зубів в основній групі дітей використовували спосіб мікроінвазивного лікування безпорожнинного карієсу емалі методом інфільтрації за допомогою сучасного матеріалу «Icon» (ф. DMG, Німеччина). Гострий поверхневий, середній та глибокий карієс зубів у дітей лікували шляхом препарування і пломбування. Відновлення анатомічної форми зуба проводили з використанням склоіономерних цементів: Ionofil Molar ( $\phi$. VOCO, Німеччина), Ketac Molar ( $\phi .3 \mathrm{M}$ ESPE, CША), Fuji IX GP (ф. GC, Японія). Лікування гострого глибокого карієсу проводили в два відвідування. В якості лікувальних прокладок у перше відвідування використовували пасти з протимікробними, протизапальними та анестезуючими властивостями: «Кариосан» (Чехія), «Эодент» (ф. ВладMИВА, Росія), IRM ( $\phi$. Dentsply, CША), «Templin» (ф. PSP Dental, Англія), «Ledermix», «Zinoment» ( $\phi$. VOCO, Німеччина). В друге - одонтотропні пасти: «Calcimol» ( $\phi$. VOCO, Німеччина), «Life» (Kerr, CШA), MTA ProRoot (США).

3 метою профілактики розвитку карієсу зубів у дітей основної групи розроблений комплекс профілактичних заходів, що включає лікарську та безлікарську профілактику. Лікарська профілактика включала: крем «GC MI Paste Plus» - аплікації один раз на добу, до розчинення в порожнині рота, протягом місяця; препарат «Імудон» - дітям старше 14 років рекомендовано приймати по 8 табл. на добу 3 інтервалом 1 год, тривалість курсу 10 днів; 3 метою профілактики захворювань порожнини рота та глотки - по 6 табл./добу, тривалість курсу - 20 днів; полівітамінний комплекс «Алфавіт Школяр" протягом місяця. Безлікарська профілактика включала: нормалізацію розпорядку дня, праці та відпочинку, а також раціональне харчування (для зміцнення соматичного здоров'я); герметизацію слабомінералізованих інтактних фісур молярів та премолярів зубів емаль герметизуючою рідиною
(«Тифенфлюорид», НСН, Німеччина) двічі на рік; застосування зубної пасти «R.O.C.S. Активний кальцій», потім "R.O.C.S. Teens (8-18 poків)» двічі на день по 15 днів кожною, ополіскувача для ротової порожнини «R.O.C.S. «COOL MIX» 2-3 рази на день протягом 30 с після або у проміжках між чищеннями зубів; споживання твердих свіжих овочів та фруктів.

Лікування хворих групи порівняння проводили відповідно до прийнятих в Україні Протоколів надання медичної допомоги за спеціальністю "Дитяча терапевтична стоматологія», затверджених МОЗ України наказом № 566 від 23.11.2004 p.

Повторні курси лікувально-профілактичних заходів для підвищення мінералізуючих і захисних властивостей ротової рідини та поліпшення гігієни порожнини рота проводили кожні півроку.

Достовірність отриманих результатів оцінювали за критерієм Стьюдента. Статистичне обчислення матеріалів проводили відповідно до рекомендацій [9].

Результати досліджень та їх обговорення. Стан гігієни порожнини рота, фізико-хімічні та мінералізуючі властивості ротової рідини в процесі лікування дітей 8-12 та 13-16 років 3 ЮРА наведено в таблицях 1 і 2.

Згідно 3 поданими даними, до лікування значної різниці між дослідженими показниками у дітей основної та порівняльної груп обох вікових періодів не встановлено, за винятком мікрокристалізації слини. Разом 3 тим, після проведення комплексу лікувальнопрофілактичних заходів у дітей основної групи спостерігалось достовірне поліпшення усіх показників стану гігієни порожнини рота, швидкості виділення слини та її $\mathrm{pH}$.

Відомо, що регулярний гігієнічний догляд за порожниною рота сприяє зменшенню вірогідності розвитку карієсу зубів. Вивчення індексу Гріна-Вермільйона після проведення лікувально-профілактичного курсу в дітей основної групи виявило поліпшення показника OHI-S в 3,7 раза у другому дитинстві й 5,3 paза в підлітків порівняно 3 вихідним рівнем $\left(\mathrm{p}_{2}<0,001\right)$. Аналогічне поліпшення показника стану гігієни ротової порожнини (відповідно в 2,8 i 3,3 раза при $\left.\mathrm{p}_{3}<0,001\right)$ виявлено у дітей групи порівняння, що також вказувало на ефективність традиційного методу лікування і профілактики карієсу в пацієнтів з ЮРА. Незважаючи на те, що стан гігієни порожнини рота після лікування у дітей основної та 
таблиця 1. Результати дослідження стану гігієни порожнини рота, рН ротової рідини, швидкості

іiї виділення та мінералізуючих властивостей у процесі лікування дітей другого дитинства з ЮРА

\begin{tabular}{|l|c|c|c|c|}
\hline \multirow{2}{*}{ Показник дослідження } & \multicolumn{3}{|c|}{ Обстежені діти другого дитинства (8-12 років) } \\
\cline { 2 - 5 } & основна група хворих дітей з ЮРА & \multicolumn{1}{c|}{$\begin{array}{l}\text { порівняльна група хворих дітей } 3 \\
\text { ЮРА (n=14) }\end{array}$} \\
\cline { 2 - 5 } & до лікування & після лікування & до лікування & після лікування \\
\hline $\begin{array}{l}\text { Iндекс гігієни Гріна-Вер- } \\
\text { мільйона }\end{array}$ & $1,69 \pm 0,1$ & $0,46 \pm 0,05$ & $1,74 \pm 0,11$ & $0,62 \pm 0,06$ \\
\hline $\mathrm{p}$ & $\mathrm{p}_{1}>0,05$ & $\mathrm{p}_{2}<0,001$ & $\mathrm{p}_{3}<0,001$ & $\mathrm{p}_{4}<0,05$ \\
\hline $\mathrm{pH}$ & $6,53 \pm 0,08$ & $7,06 \pm 0,05$ & $6,64 \pm 0,1$ & $6,93 \pm 0,04$ \\
\hline $\mathrm{p}$ & $\mathrm{p}_{1}>0,05$ & $\mathrm{p}_{2}<0,001$ & $\mathrm{p}_{3}<0,01$ & $\mathrm{p}_{4}<0,05$ \\
\hline $\begin{array}{l}\text { Швидкість слиновиділен- } \\
\text { ня (у мл/хв) }\end{array}$ & $0,44 \pm 0,02$ & $0,5 \pm 0,01$ & $0,44 \pm 0,01$ & $0,47 \pm 0,01$ \\
\hline $\mathrm{p}$ & $\mathrm{p}_{1}>0,05$ & $\mathrm{p}_{2}<0,01$ & $\mathrm{P}_{3}>0,05$ & $\mathrm{p}_{4}<0,05$ \\
\hline КОШРЕ-тест (у днях) & $5 \pm 0,17$ & $1,53 \pm 0,13$ & $4,57 \pm 0,4$ & $2,79 \pm 0,24$ \\
\hline $\mathrm{p}$ & $\mathrm{p}_{1}>0,05$ & $\mathrm{p}_{2}<0,001$ & $\mathrm{p}_{3}<0,001$ & $\mathrm{p}_{4}<0,001$ \\
\hline КОШРЕ-тест (у відсотках) & $56,67 \pm 1,87$ & $17,33 \pm 1,53$ & $52,14 \pm 4,59$ & $30 \pm 2,34$ \\
\hline $\mathrm{p}$ & $\mathrm{p}_{1}>0,05$ & $\mathrm{p}_{2}<0,001$ & $\mathrm{p}_{3}<0,001$ & $\mathrm{p}_{4}<0,01$ \\
\hline $\begin{array}{l}\text { Мікрокристалізація } \\
\text { слини (у балах) }\end{array}$ & $1,67 \pm 0,27$ & $3,93 \pm 0,27$ & $2,64 \pm 0,41$ & $3,36 \pm 0,25$ \\
\hline $\mathrm{p}$ & $\mathrm{p}_{1}<0,05$ & $\mathrm{p}_{2}<0,001$ & $\mathrm{p}_{3}>0,05$ & $\mathrm{p}_{4}>0,05$ \\
\hline
\end{tabular}

Примітки: 1) $\mathrm{p}_{1}$ - достовірність різниці показників між дітьми з ЮРА основної та порівняльної груп до лікування;

2) $\mathrm{p}_{2}$ - достовірність різниці показників між дітьми з ЮРА основної групи до та після лікування;

3) $\mathrm{p}_{3}$ - достовірність різниці показників між дітьми з ЮРА порівняльної групи до та після лікування;

4) $\mathrm{p}_{4}$-достовірність різниці показників між дітьми з ЮРА основної та порівняльної груп після лікування.

порівняльної груп в обох вікових періодах за показниками OHI-S оцінено як хороший, при їх порівнянні різниця середньостатистичних значень їх результатів мала високий ступінь достовірності $\left(\mathrm{p}_{4}<0,05\right)$, що вказувало на переважання розробленого нами лікувально-профілактичного методу.

При аналізі основного показника гомеостазу ротової порожнини - рН виявлено, що концентрація іонів $\mathrm{H}^{+}$у змішаній слині основної і порівняльної груп після лікування мала стійку тенденцію до підвищення як у віковому періоді 8-12 років, так і 13-16 років зі ступенем достовірності відносно початкового рівня 99-99,9 \%. Проте результати в основній групі дітей з ЮРА були помітно кращі $\left(\mathrm{p}_{4}<0,05\right)$.

Про позитивні зміни швидкості слиновиділення у дітей основної групи обох вікових періодів свідчило достовірне покліпшення цього показника відносно вихідного рівня $\left(\mathrm{p}_{2}<0,01\right)$, разом $з$ тим, як у групах порівняння незначне підвищення середньостатистичних значень було недостовірним $\left(\mathrm{p}_{3}>0,05\right)$.

У процесі комплексного лікування і профілактики карієсу зубів спостерігали норма- лізацію ремінералізуючої здатності слини та підвищення стійкості емалі до дії кислоти. Так, після проведення лікувально-профілактичного комплексу в основній групі дітей 3 ЮРА ступінь сприятливості емалі зубів до дії кислоти зменшився утричі $\left(\mathrm{p}_{2}<0,001\right)$ у другому дитинстві й у 3,5 раза $\left(\mathrm{p}_{2}<0,001\right)$ - у підлітковому віці та збільшилась ремінералізуюча властивість ротової рідини відповідно в 3 і 3,6 раза $\left(\mathrm{p}_{2}<0,001\right)$. Вивчення мікрокристалізації слини також підтвердило високий рівень мінералізуючого потенціалу слини після лікування дітей основної групи. При цьому виявили велику кількість кристалів 1 і 2 типів та у поодиноких випадках - 3 типу.

На відміну від основної групи, поліпшення ремінералізуючих властивостей ротової рідини та карієссприятливості емалі в обстежених дітей груп порівняння були менш вираженими, а в деяких випадках і недостовірними $\left(\mathrm{p}^{3}>0,05\right)$. Проте після лікування простежувалась стійка тенденція до вірогідності різниці середньостатистичних показників між результатами основних та порівняльних груп $\left(\mathrm{p}_{4}<0,001\right)$, що підкреслювало перевагу запро- 
Таблищя 2. Результати дослідження стану гігієни порожнини рота, рН ротової рідини, швидкості ії виділення та мінералізуючих властивостей у процесі лікування дітей підліткового віку з ЮРА

\begin{tabular}{|l|c|c|c|c|}
\hline \multirow{2}{*}{ Показник дослідження } & \multicolumn{3}{|c|}{ Обстежені підлітки (13-16 років) } \\
\cline { 2 - 5 } & $\begin{array}{c}\text { основна група хворих дітей 3 ЮРА } \\
(\mathrm{n}=13)\end{array}$ & \multicolumn{2}{c|}{$\begin{array}{c}\text { порівняльна група хворих дітей } 3 \\
\text { ЮРА (n=13) }\end{array}$} \\
\cline { 2 - 5 } & до лікування & після лікування & до лікування & після лікування \\
\hline $\begin{array}{l}\text { Індекс гігієни Гріна-Вер- } \\
\text { мільйона }\end{array}$ & $1,9 \pm 0,09$ & $0,36 \pm 0,05$ & $1,72 \pm 0,13$ & $0,52 \pm 0,05$ \\
\hline $\mathrm{p}$ & $\mathrm{p}_{1}>0,05$ & $\mathrm{p}_{2}<0,001$ & $\mathrm{p}_{3}<0,001$ & $\mathrm{p}_{4}<0,05$ \\
\hline $\mathrm{pH}$ & $6,52 \pm 0,06$ & $6,99 \pm 0,05$ & $6,49 \pm 0,06$ & $6,85 \pm 0,04$ \\
\hline $\mathrm{p}$ & $\mathrm{p}_{1}>0,05$ & $\mathrm{p}_{2}<0,001$ & $\mathrm{p}_{3}<0,001$ & $\mathrm{p}_{4}<0,05$ \\
\hline $\begin{array}{l}\text { Швидкість слиновиділен- } \\
\text { ня (у мл/хв) }\end{array}$ & $0,44 \pm 0,03$ & $0,52 \pm 0,01$ & $0,41 \pm 0,02$ & $0,45 \pm 0,02$ \\
\hline $\mathrm{p}$ & $\mathrm{p}_{1}>0,05$ & $\mathrm{p}_{2}<0,05$ & $\mathrm{p}_{3}>0,05$ & $\mathrm{p}_{4}<0,001$ \\
\hline КОШРЕ-тест (у днях) & $5,23 \pm 0,23$ & $1,38 \pm 0,14$ & $5 \pm 0,3$ & $2,46 \pm 0,24$ \\
\hline $\mathrm{p}$ & $\mathrm{p}_{1}>0,05$ & $\mathrm{p}_{2}<0,001$ & $\mathrm{p}_{3}<0,001$ & $\mathrm{p}_{4}<0,001$ \\
\hline кОшРЕ-тест (у відсотках) & $55,38 \pm 3,12$ & $16,15 \pm 1,4$ & $52,31 \pm 2,81$ & $26,92 \pm 2,37$ \\
\hline $\mathrm{p}$ & $\mathrm{p}_{1}>0,05$ & $\mathrm{p}_{2}<0,001$ & $\mathrm{p}_{3}<0,001$ & $\mathrm{p}_{4}<0,01$ \\
\hline $\begin{array}{l}\text { Мікрокристалізація } \\
\text { слини (у балах) }\end{array}$ & $1,62 \pm 0,33$ & $3,77 \pm 0,28$ & $1,85 \pm 0,4$ & $3,36 \pm 0,25$ \\
\hline $\mathrm{p}$ & $\mathrm{p}_{1}<0,05$ & $\mathrm{p}_{2}<0,001$ & $\mathrm{p}_{3}<0,01$ & $\mathrm{p}_{4}>0,05$ \\
\hline
\end{tabular}

Примітки: 1) $\mathrm{p}_{1}$ - достовірність різниці показників між дітьми з ЮРА основної та порівняльної груп до лікування;

2) $\mathrm{p}_{2}$ - достовірність різниці показників між дітьми з ЮРА основної групи до та після лікування;

3) $\mathrm{p}_{3}$ - достовірність різниці показників між дітьми з ЮРА порівняльної групи до та після лікування;

4) $\mathrm{p}_{4}$ - достовірність різниці показників між дітьми з ЮРА основної та порівняльної груп після лікування.

понованого методу лікування та профілактики карієсу зубів у дітей з ЮРА.

Висновки. Застосування розробленого комплексного методу лікування і профілактики карієсу зубів у дітей з ЮРА, сприяло значному покращенню показників стану ротової порожнини у порівнянні з традиційним підходом.

Висока ефективність розпрацьованого методу підтверджувалась достовірним підви-

\section{Список літератури}

1. Адмакин О. И. Клинико-иммунологическая характеристика состояния органов полости рта у детей с ювенильным ревматоидным артритом / О. И. Адмакин, Ю. А. Козлитина // Стоматология. 2011. - № 6. - С. 77-79.

2. Гігієна дітей та підлітків : підручник / В. І. Берзінь [та ін.]. - К. : Асканія, 2008. - 340 с.

3. Гринин В. М. Особенности развития кариеса зубов и его осложнений у больных ревматоидным артритом / В. М. Гринин, А. А. Скворцова // Российский стоматологический журнал. - 2011. - № 2. - С. 17-19. 4. Гришкян А. Р. Особенности оказания терапевтической стоматологической помощи больным щенням кислотно-лужного стану порожнини рота, поліпшенням рівня ії індивідуальної гігієни і структурних властивостей ротової рідини та суттєвим впливом на інтенсивність слиновиділення, що забезпечувало реалізацію важливих ремінералізуючих функцій змішаної слини.

Розроблений комплексний метод лікування і профілактики каріозного ураження зубів у дітей з ЮРА може бути рекомендований для впровадження в практичну охорону здоров’я.

ревматоидным артритом : автореф. дисс. на соискание уч. степени канд. мед. наук : спец. 14.01.21 «Стоматология» / А. Р. Гришкян. - М. , 2008. - С. 23.

5. Диагностика и дифференциальная диагностика кариеса зубов и его осложнений: уч. пособ. / В. Ф. Михальченко, Л. И. Рукавишникова, Н. Н. Триголос, А. Н. Попова // - М. : АОр «НПП Джангар», 2006. - 104 с. 6. Кулигіна В. М. Результати вивчення карієссприятливості емалі зубів та ремінералізуючого потенціалу змішаної слини у дітей з ювенільним ревматоїдним артритом / В. М Кулигіна, О. Ю. Пилипюк // Вісник проблем біології і медицини. - 2015. - № 2, T. III. - C. 359-362. 


\section{Терапевтична стоматологія}

7. Кулигіна В. М Показники дослідження швидкості слиновиділення, pН-ротової рідини і стану кислотно-лужної рівноваги у дітей з ювенільним ревматоїдним артритом / В. М. Кулигіна, О. Ю. Пилипюк // Клінічна та експериментальна патологія. - 2015. № 1, T. XIV. - C. 84-88.

8. Кулигіна В. М. Результати клінічного обстеження пацієнтів із захворюваннями слизової оболонки порожнини рота, поєднаними 3 ревматоїдним артритом / В. М. Кулигіна, А. В. Повшенюк // Буковинський медичний вісник. - 2015. - № 1. - С. 88-92.

9. Реброва О. Ю. Статистический анализ медицинских данных. Применение пакета прикладных про- грамм STATISTICA : уч. пособ. / О. Ю. Реброва. - М. : Медиа Сфера, 2002. - 312 с.

10. Сайфуллина X. М. Кариес зубов у детей и подростков / Х. М. Сайфуллина. - М. : Медпресс, 2000. $-96 \mathrm{c.}$

11. Стоматологія (терапевтична, ортопедична, хірургічна, дитяча). Ортодонтія. Протоколи надання медичної допомоги : зб. норм. док. / МОЗ України, Київський МНІАЦ мед.стат. - К. : МНІАЦ медичної статистики, МВЦ «Медінформ», 2012. - 236 с.

12. Пропедевтика дитячої терапевтичної стоматології: підручник / Л. О. Хоменко [и др.]; ред. Л. О. Хоменко; НМУ ім. О. О. Богомольця. - К. : Книга плюс, 2011. - C. 320.

Отримано 15.07.16 